\title{
Designing Picture Book of Religious Education and Science for Children Based on Multiple Intelligence
}

\author{
Aditya Rahman Yani and Amierza Puspaningrum
}

\begin{abstract}
Religious education and science are very important in children knowledge development in the golden age. It because brain development of children growth fast at that age, especially in terms of learning. However, each child has a different learning style. Patterns of information can be easily and well accepted by the children if we use a learning style which is reflected their intelligence tendency (based on multiple intelligence). If a child is capable of capturing the information or material about science and religious education according to their learning styles, then there will be no material that is difficult to understand.

In the middle of the various media of learning, book is the one medium that allows for early childhood learning. Then this paper will explain how to design a book of Islamic religious education and science for early childhood (2-4 years old) through a variety of learning styles that match with multiple intelligence.

Animals that are mentioned in the Koran can be an example representing the combination of Islamic education with science. This book will bring up various animal characters through stories, as presented in the Koran, then it will be explained from the point of view of science. The contents of the book will be delivered with a playful language style, visualized with a simple vector images, funny, interesting, and also colourful. The addition of interactive media on each chapter and finger puppets used to support success in applying the various styles of children's learning.
\end{abstract}

Index Terms-Animal, picture book, multiple intelligence, religious.

\section{INTRODUCTION}

Education is an important asset for the progress of a nation, therefore every citizen must follow the hierarchy of education, startsfrom early childhood education, elementary education, middle education and higher. According to the term itself, education has a lot of the definition because it has a wide aspect. But in fact, education is the process of repair, strengthening, and the consummation of all human ability [1] Early childhood education is the first stage of the whole educational process. At this stage, there is a coaching effort that is intended for children from birth up to the age of six years through the provision of educational stimulation to help the physical and spiritual development of children [2].

A research said that the growth of brain cell in 0-4 years old children reaches $50 \%$, and it will rise until $80 \%$ in age of 8 years, so that the experts called the period of the childhood development as "golden age" that occurs only one time in

Manuscript received August 5, 2014; revised October 16, 2014.

The authors are with the Universitas Pembangunan Nasional "Veteran" JawaTimur, Indonesia. (e-mail: saimuslim@gmail.com, amierzapuspa@gmail.com). human life [3]. That is the most appropriate time to put the basics development of physical skills, language, social, emotional, self concept, morality, and religious values. Children need to be guided in a good way and in accordance with their age, so that later they become excelled in both religious and intellectual. It because of early childhood development is strongly influence the children development of later [4].

In addition to the topics related to science (as it become a priority of public schools), education must also principled on moral values and religion. This is very necessary in an effort to educate the child toward maturity of thinking, behave, and attitude (akhlakul al-karimah). Such efforts could be made by educators (teachers and parents) from an early age, i.e. when childhood [5].

Parents have an important role because parents are the closest relatives that could be model by the children. Parents can start by focussing on basic education such as physical growth and development (gross and fine motor skill coordination), intelligence (intellectual, creativity, emotional intelligence, and spiritual intelligence), as well as the socio-emotional (attitudes, behaviour and religion), language and communication adapted to the uniqueness and the stages of early childhood development [6].

However, it is not easy teaching material about religious education and science to children because each child's learning style is not always the same. Pattern of information would be accepted easily and well by the children if it is delivered with appropriate learning style according to a tendency of their intelligence (multiple intelligence) [3]. Children who have a tendency in linguistic intelligence have a different learning style with other kids who have a tendency to intrapersonal intelligence. Likewise the other children who have a tendency in naturalist, musical, logical-mathematical, visual-spatial, interpersonal and kinesthetic, they all have a different learning style depend on the changeable environmental conditions. If a child is able to capture any information or material through the way that suits his/her learning style, then there will be no material that is difficult to understand.

In theage of various learning media, the book is one of the best media in early childhood learning. It can encourage children to love reading. According to Paul C. Burn [7], reading is a complex process because it involves eight aspects; knowledge, perception, sequential, experience, thinking, learning, associations and affection. In other words, thateight aspects can work simultaneously when we doing one activity called reading.

For children in the early age, picture book with few word or commonly called WPB (Wordless Picture Book) is a good 
learning medium in order to stimulate them to love reading. The power of illustration, character design, capability and use of rich color composition, all of that are useful for attracting children to read [7]. The use of a comical figure through the character of animals that can speak could be a viable option for educators to help children understand the story easily. The characters will be made to rise children's fantasy and imagination.

One of the themes that could be an example of a blend of Islamic education with science is about the animals that are discussed in the Koran. The importance of this theme is also based on the Prophet (p.b.u.h.) in the Hadith "Love anyone on earth, then you will be loved by anyone who is in the heavens". It affirms that Islam requires to understand each other and love all living creatures in the universe as proof of adherence to the Creator that is God. The golden age is the right moment to instill religious morals and knowledge, especially about living creatures and basic science that deals with them.

The chosen topic of animals that exist in the Koran can be a stimulus for the children to get to understand Islam early on, while the addition of knowledge about these animals will become a scientific insight for children.

The characteristics of children who become targets of these picture books are aged 3-6 years, have a high interest towards new things, creative, critical, curious, cheerful, have an interest to read book, like reading together with parents or teachers, and love to play around.

As decision maker, the parents, or in particular the mothers, also become the main target of this book because they have an important role on conveying contents of the book to their children. Without parents (especially mothers), it will be a lot of features of this book which does not function optimally. They are 25-35 years old mothers, have children aged 3-6 years, working, middle-class, have personal income of around IDR. 2,500,000 - IDR. 5,000,000 per month, high-educated (minimum Bachelor's degree), critical, insightful (especially about early childhood education), and generally live in large urban areas.

\section{Design Methodology}

The method in designing this picture book as follows:

\section{A. Recognize the Problem}

In this stage, there are some researches to find out the crucial problems in the education of religion and science for early childhood, as well as finding out the solution through interview with experts, questionnaires, observation and literatures.

\section{B. Formulate Design Concept}

In this stage, the designer performs data analysis resulting from the research that has been done before, and then formulate creative ideas in the form of the design concept.

\section{Determine Design Criterias}

In this stage, the designer describes the design concept into design criterias. These criterias include the visual aspects, messages and media specifications.

\section{Alternative Design}

In this stage, the designer explores the design concept into alternative design choices, then selecting the best one for final design.

\section{E. Design Implementation}

Design implementations are gained after the final design was chosen from some alternatives that have been questionnaired.

\section{DESIGN CONCEPT}

The main concept of this picture book represented in a keyword: "Islamic Cheerful Education", that means "making Islamic and science education as a fun activity for children in early childhood".

The Picture books about animals in the Koran will be designed as one alternative learning which combines science with religion,in a fun, interactive, and effective learning method.

\section{A. Unique Selling Preposition (USP)}

If this picture book seen through visual and verbal aspects, there are several advantages that become differentiators with other illustrated books in general. This book contains interesting stories about animals in the Koran that occurs at the time of the Prophets, and also explaining their behavior and life in the context of science. Visually, this book presents a vector image style and tone bright colors, to give comfort and interest on all materials presented in this book. The use of simple-detail image style - without changing the proportions of the original form of animals - can help children grasp the object easily.

The other advantages and uniqueness of this picture book are on some features that support the childhood learning styles (according to multiple intelligences) as follows:

1) There are narrativess which contains stories about the interaction of the Prophets with the animals in ancient times, which support the learning style of children who have a tendency on linguistic intelligence.

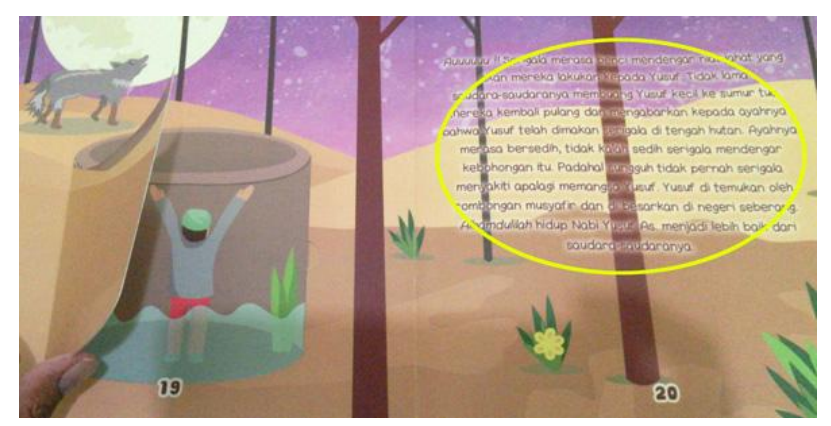

Fig. 1. Narration to support linguistic intelligence.

2) There are interactive mechanism on every page such as flip-flap page (open a window on the page of the book), volvelles (wheel or circular shaft rotate in clockwise direction), and the slide objects (shift to the right or left to play the object), that created to support the learning style of children who have a tendency on spatial-visual and kinesthetic intelligence. 


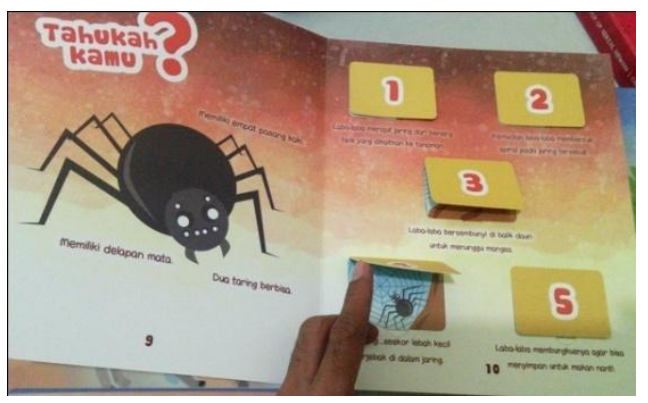

Fig. 2. Flip-flap page to support visual and kinesthetic intelligence.

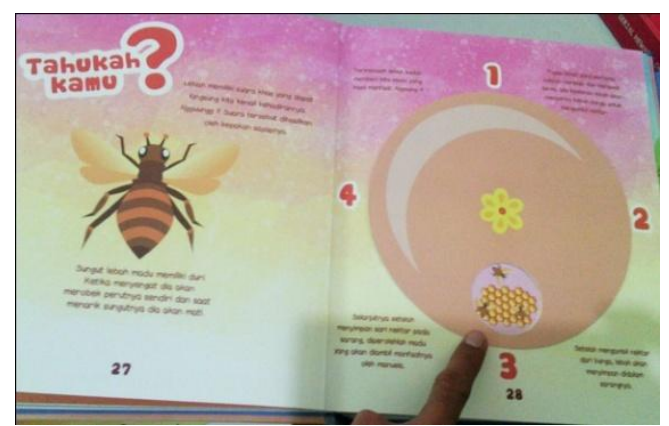

Fig. 3. Volvellespage to support visual and kinesthetic intelligence.

3) There are suggestions to encourage children to see directly the animals discussed in the book, and then make photo documentation for pasting on a page that has been provided. This activity supports the learning style of children who have a tendency on naturalist, interpersonal and kinesthetic intelligence.

4) There are suggestions to encourage children to write poetry about animals that are discussed in the book. This activity supports the learning style of children who have a tendency on musical intelligence.

5) There are exercises to encourage children to count the number of animals found in pages. This activity supports the learning style of children who have a tendency on logical-mathematical intelligence.

\section{B. Arrangement of the Contents of the Material}

The book will be divided into 2 series and each series discusses five animals selected from the Quran. The order of contents on each picture book are front cover, page of ownership, colophon, title page, main material, end note, bibliography, closing page, and rear cover.

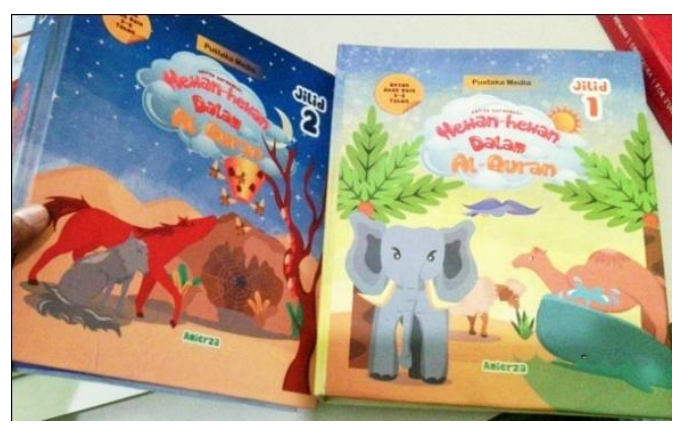

Fig. 4. Two series book covers.

\section{Description of the Content}

\section{1) Page of ownership}

This post contains words "This Book belongs to......." with blank space that can be filled according to the name of the owner.

2) Colophon

Contains the author, editor, publisher and copyright laws.

3) Title page

Contains the title of the book.

\section{4) Main Material}

Each book will discuss five stories of animals as well as other features that support children's learning styles according to multiple intelligence.

For example, a chapter describes the story of a whale. First, this chapter will start with the story of the prophet Yunus as. (Jonah) being swallowed by whale as mentioned in the Koran surah Al-Anbiyaa' 87. Second, explain about how whale survive, proliferate, and also food. Third, interactive flip-flap technique, volvelles, and slide. Fourth, an invitation to watch whales from the video which is attached in the CD Appendix. Fifth, suggestion to create a poem about whale by mentioning its characteristics, then ask others to find out the answer. Sixth, suggestion to count the number of animals.

\section{5) Closing page}

In the closing page, there are bibliography and end-note-page that contains full version of verseswhich become the source of the animal story.

\section{Communication Strategy}

The dialogue and narrative in this picture book will use informal language style to build on relax and enjoyable while reading. It will not tie to Indonesia's formal language rules. Imitation of natural sounds, such as sound waves, and wind and animals, added to the narrative of this book in order to help the dramatization of the story.

Another communication strategy in this book is finger puppet. It will be used as additional media to support the parents to tell the story to their children. Storytelling makes children enjoy the content of books [7].

\section{E. Visual Strategies}

This picture book will use a simple image style. The drawing will not focus on the details of the object to help children imagine the story easily. Drawing technique will use digital vector which is not too complicated in iconography but still looks cute and interesting. Simple image style without changing the proportions of the original form - is expected to understand by children easily.

Pictures or artwork will be the dominant element in comparison with the text in this book. It because artwork can stimulate children's imagination on the material conveyed in this book [8].

For title and headings, this book will use typeface that has the impression of funny and childish but still have a high level of readability, such as Cookies. While the body text will use Bigness font, because this typeface looks cute and belongs in sanserif typeface so it can be read clearly even though used in long sentence [9].

The overall picturein this book will be designed colorfully with playing bright colors composition because it is specifically targeted to children who are reflecting their personality: cheerful and impassioned. 


\section{F. Book Specification.}

- Printed onpaper $20 \times 20 \mathrm{~cm}^{2}$.

- Using $3 \mathrm{~mm}$ thick carton paper.

- Hardcover.

- Blunt cutting for every corner.

\section{CONCLUSION}

Designing picture book that supports religious and science education by using appropriate learning style according to multiple intelligences can be an effective medium for parents to instill religious values and science to children. If learning styles that are used by parents in match with the interests of the children, then the material will be easy to understand. This picture book also can be used by educational institutions to support early childhood learning curriculum which already exists.

Hopefully this picture book can be a guide for parents and teachers to teach their children to understand Islam and expected to become good Muslim with high-intellectual, good attitude, graceful and skillful in charity, so they would be able to live in competitive life without losing their true identity as Muslim.

\section{ACKNOWLEDGMENT}

We would like to express our appreciation to Heru Subiyantoro, ST., MT. for giving us advice to fix this paper. We would particularly like to thank our family for giving us motivation, and also the following people in our Department for their assistance in our data collection: Aryo Bayu Wibisono, Aris Sutejo and Siti Hanna.

\section{REFERENCES}

[1] R. Moh, Ilmu Pendidikan Islam: Pengembangan Pendidikan Integratif di Sekolah, Keluarga, dan Masyarakat, Islamic Education Knowledge: Development of Integral Education in School, Family, and Society, Yogyakarta: LkiS, 2009, p. 14.

[2] A. Puspaningrum and A. R. Yani, "Buku visual pengenalan hewan dalam al-quran untuk anak usia dini," Visual Book to Introduce Animals in the Koran for Children, Createvitas, vol. 3, no. 2, pp. 211-226, July 2014.

[3] C. Munif, "Orangtuanya manusia: melejitkan potensi dan kecerdasan dengan menghargai fitrah setiap anak," Human's Parents: Rising Potential and Intelligence with Appreciating Children, Bandung: Penerbit Kaifa, 2012, pp. 13-171.

[4] Y. Martinis and J. S. Sanan, "Panduan anak usia dini," Guide For Early Childhood, Jakarta: GIP Press, 2010, p. 5.

[5] A. I. Qoyyim, "Tuhfatul maudud bi ahkamil maulud," The Best Values of Birth Law, Mesir: Darul 'Aqidah, 2006, p. 21

[6] H. Maiumunah, "Pendidikan anak usia dini: panduan lengkapmanajemen mutu pendidikan anak untuk para guru dan orang tua," Early Childhood Education: Complete Guide To Manage Children Education Quality for Teachers and Parents, Yogyakarta: Diva Press, 2011, p. 17.

[7] A. M. Fauzil, "Membuat anak gila membaca," Make Your Children Love Reading, Bandung: Penerbit Mizania, 2007, pp. 25-91

[8] R. Surianto, "Layout dasar dan penerapannya," Basic Layout and its Application, Jakarta: PT Gramedia Pustaka Utama, 2009, p. 57.

[9] R. Surianto, Hurufontipografi, typeface-font-typography, Jakarta: PT Gramedia Pustaka Utama, 2011, p. 81.

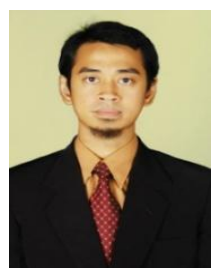

Aditya Rahman Yani was born in Madiun, East Java, Indonesia on September 29, 1981. He finished his bachelor degree in visual communication design, Institut Teknologi Sepuluh Nopember Surabaya, East Java, Indonesia in 2005, and his master degree in media and communication, Universitas Airlangga Surabaya, East Java, Indonesia in 2010.

$\mathrm{He}$ is a lecturer in Visual Communication Department, Universitas Pembangunan Nasional "Veteran" Jawa Timur, Indonesia.

Mr. Yani has research interests in visual art (especially for education learning), visual analysis, and Islamic art, such as "Representation of Malayan ethnic in an Animation Film Upin \& Ipin", "Representation of Postmodernism in Islamic Movie Women with a Turban", "Jihad in Visual Artwork of Muslim Punk Subculture", and "Ethic and Aesthetic in Islamic Art and Western Art".

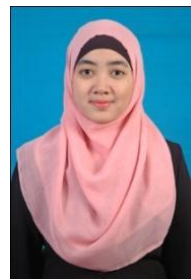

illustration.
Amierza Puspaningrum was born in Gresik, East Java, Indonesia on July 16, 1992. She finished her bachelor degree in visual communication design, Universitas Pembangunan Nasional "Veteran" Jawa Timur, Indonesia, in 2010 .

She is a professional illustrator and student facilitator in Universitas Pembangunan Nasional "Veteran" Jawa Timur, Indonesia.

Ms. Puspaningrum has research interest in visual 